\title{
Testing reliability of a potential island mating apiary using DNA microsatellites
}

\author{
Peter Neumann ${ }^{\text {a, b }}$, Job P. van Praagh ${ }^{c}$, Robin F.A. Moritz ${ }^{a *}$, \\ Jost H. Dustmann ${ }^{\mathrm{c}}$
}

a Martin-Luther-Universität Halle-Wittenberg, Fachgebiet Molekulare Ökologie, Institut für Zoologie, Kröllwitzerstr. 44, 06099 Halle/Saale, Germany

${ }^{b}$ Department of Zoology and Entomology, Rhodes University, Grahamstown 61440, South Africa

${ }^{c}$ Niedersächsisches Landesinstitut für Bienenkunde Celle, Wehlstr. 4a, 29223 Celle, Germany

(Received 25 July 1998; revised 21 November 1998; accepted 12 May 1999)

\begin{abstract}
Twenty-four virgin sister queens were kept for 21 days in mating nuclei on the drone-free island Baltrum to test the reliability of a potential mating area. On each of the neighbouring islands Norderney and Langeoog ( $750 \mathrm{~m}$ and $2 \mathrm{~km}$ away) 12 sister queens were kept with drones. Workers from colonies with island-mated queens (Baltrum $n=11$, Langeoog $n=7$ and Norderney $n=6$ ) were genotyped with four DNA microsatellite loci $(n=996)$ to estimate queen mating frequency. No differences in queen mating frequency were observed between Langeoog and Norderney. However, the level of polyandry on Baltrum was significantly lower than on the neighbouring islands, indicating that mating conditions were much more difficult. The standard genetic distance and differences in allele frequencies between the populations were determined to estimate putative origins of the drones. In this study, $43.7 \%$ of the identified drone fathers did not descend from any of the queens on the adjacent islands. They were most likely from mainland colonies at least $5.4 \mathrm{~km}$ ( $3 \mathrm{~km}$ across open water) away, showing that the combination of distances over open water and over dry land is important in explaining the mating behaviour of honeybee queens. (C) Inra/DIB/AGIB/Elsevier, Paris
\end{abstract}

Apis mellifera / DNA microsatellite / island / mating control / polyandry

\section{INTRODUCTION}

Islands are routinely used as mating apiaries to achieve controlled matings of virgin queens [34]. The large areas of open water around islands have a negative impact on the orientation of honeybee workers during their flights [15]. Thus, islands have been claimed to be ideal places because queens and drones are not expected to cross open

\footnotetext{
* Correspondence and reprints

E-mail: r.moritz@zoologie.uni-halle.de
} 
water during their mating flights. However, bee breeders have repeatedly reported uncontrolled matings even on these safe island mating areas. Recent studies of queen honeybee mating behaviour on drone-free islands strongly support these observations because they reveal that queens returned from their nuptial flights with a mating sign even during high tide [33].

So far, the reliability of mating apiaries has been tested using virgin queens without drone colonies $[5,10,17-19,21,27$, 31], displacement experiments of drones [5, $11,20]$ and marker phenotypes such as different races $[2,28]$ or mutants such as cordovan [29]. Whereas some islands seem to provide controlled matings (e.g. [5, 20]) others apparently do not ([29] among others). A key factor is the distance between island and mainland. Successful mating flights of virgin queens of more than $10 \mathrm{~km}$ across open water have never been reported $[10,21,30,31]$. Virgin queens were able to cross at least $1 \mathrm{~km}$ or less across open water $[19,29]$. There are also reports on matings $7-8 \mathrm{~km}$ across open water $[17,18]$. Other authors $[5,20]$ could find no evidence of such long mating distances across open water for several North Sea islands. Thus, it seems as if distinct local characteristics of an island mating apiary are also important.

In addition to the problems resulting from unusual test conditions [29] also the cordovan test may suffer from the pitfall of the marker phenotypes interfering with honeybee behaviour as shown for workers [13]. The recent advance in honeybee DNA microsatellite technology $[8,9]$ allows for a genetical control of the reliability of mating apiaries without interfering with honeybee behaviour and routine bee breeding practice. DNA microsatellites can be used to precisely assess the number of patrilines in a honeybee colony [9]. DNA tests can be easily incorporated in the routine procedure at mating apiaries. The genotypes of the mother queen and her drone mates can be derived from worker offspring and only worker samples are needed to evaluate the number of matings of the queen. The number of queens which have mismated and the number of times these queens mated with unselected drones can be precisely determined.

In this project we tested the reliability of a potential new mating apiary on the island of Baltrum (Germany) using virgin queens and DNA microsatellites.

\section{MATERIALS AND METHODS}

\subsection{Experimental design}

Virgin sister queens $(n=48)$ were reared in summer 1995. Twenty-four of them were kept in mating nuclei on the island of Baltrum which is free of other honeybee colonies. No foraging workers could be observed before the experiments and no drones could be attracted using a lure [14] during normal drone flight activity [25]. The distances from the Baltrum apiary towards the next available drone-producing colonies on the neighbouring islands Norderney and Langeoog and on the mainland (figure I) are given in table I. On the neighbouring island mating apiaries Langeoog and Norderney 12 queens each were kept in the vicinity of 15 (Norderney) or 10 (Langeoog) drone-producing sister-queen colonies (figure I). No other bee apiaries are known on these islands. All virgin queens were allowed to mate freely during a period of 21 days. Each queen was able to absolve mating flights at the age of 7 days onwards. The queens of the drone colonies on Norderney were daughters of a single mother queen instrumentally inseminated using mixed semen [22] of drones from three sister-queen colonies. This results in a maximum number of seven alleles per locus in the worker offspring on this island. On Langeoog a maximum number of 12 alleles per locus was possible. Sealed worker brood samples $(n=50$ per queen) were taken from colonies with mated queens and raised isolated in an incubator. Recently emerged workers were immediately stored in $96 \%$ ethanol at $-15^{\circ} \mathrm{C}$ until DNA extraction. 


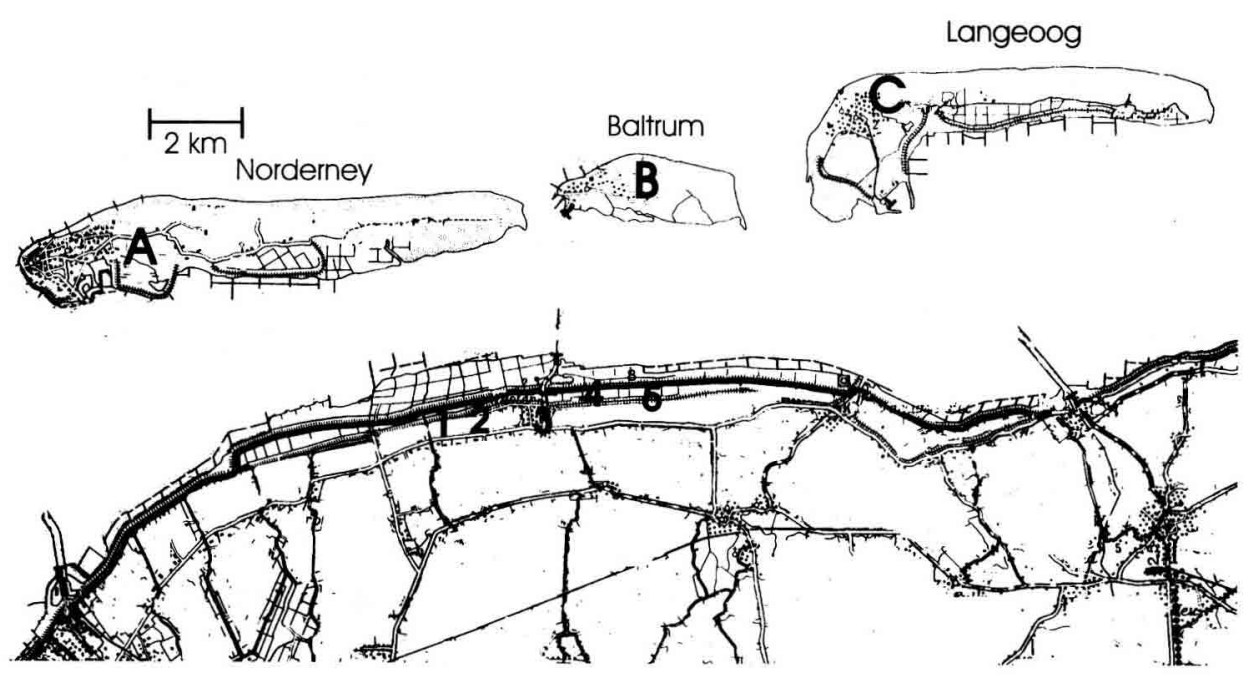

Figure 1. Map of the apiary locations on the islands Langeoog (A), Baltrum (B) and Norderney (C) and on the neighbouring mainland (1-5).

Table I. Distances from the Baltrum colonies to the next available drones sources.

\begin{tabular}{lrr}
\hline & \multicolumn{2}{c}{ Baltrum } \\
\cline { 2 - 3 } & Total & Open water \\
\hline Mainland & $5.4 \mathrm{~km}$ & $3 \mathrm{~km}$ \\
Langeoog & $7.8 \mathrm{~km}$ & $1.7 \mathrm{~km}$ \\
Norderney & $13.6 \mathrm{~km}$ & $700 \mathrm{~m}$ \\
\hline
\end{tabular}

\subsection{DNA isolation and microsatellite analysis}

DNA was phenol extracted from single workers ( $n=40$ per colony) following routine protocols [1] with the following changes:

1) workers were incubated with agitation in insect Ringer solution ( $127 \mathrm{mM} \mathrm{NaCl}, 1.5 \mathrm{mM}$ $\mathrm{CaCl}_{2}, 5 \mathrm{mM} \mathrm{KCl}, \mathrm{pH} 7.4$ with $\mathrm{NaOH}$ ) for $1 \mathrm{~h}$ at RT before extraction;

2) single worker thoraces were homogenised in $400 \mu \mathrm{L}$ of DNA extraction buffer $(100 \mathrm{mM}$ $\mathrm{NaCl}, 100 \mathrm{mM}$ Tris- $\mathrm{HCl}$ (pH 8.0), $10 \mathrm{mM} \mathrm{NaCl}$, $0.1 \%$ SDS);

3) DNA was resuspended in $30 \mu \mathrm{L} \mathrm{DDH}_{2} \mathrm{O}$.
We used four DNA microsatellites which were developed by Estoup et al. [8, 9]. Multiplex PCR was performed using two pairs of loci (A43/B 124, A76/A 107) and the standard protocols given in Estoup et al. [8,9]. Amplification products were electrophoresed on $6 \%$ polyacrylamide sequencing gels for $5.5 \mathrm{~h}$ (A76/A 107) or $5 \mathrm{~h}$ (A43/B 124) with M13mp 18 control DNA sequencing reactions run on the same gel as size standards. Microsatellite alleles were scored as fragment lengths in base pairs.

\subsection{Genotype analysis and number of matings}

The genotypes of the mother queens and the father drones were derived from the genotypes of the sampled workers. The queen was assumed to be homozygous when an allele was present in every worker of the colony. The queen was considered to be heterozygous when every worker carried one of two alleles. The paternal alleles were those not carried by the queen. We used the putative genotype of the mother queen to exclude additional allele combinations. If multiple queen genotypes were possible at a given locus we chose, as a rule, the allele combination yielding the lowest number of observed matings $\left(n_{0}\right)$. In case a drone's genotype could not be 
unambiguously determined owing to heterozygosity of the queen at that locus, we assumed an equal possibility for yielding one or the other queen allele for calculating the allele frequencies of the drone populations.

\subsection{Data analysis}

\subsubsection{Number of estimated matings $(k)$}

As a result of finite sample sizes the number of observed patrilines may severely underestimate the actual number of subfamilies. Therefore, we estimated the number of patrilines in an infinite sample following Cornuet and Aries [4]:

$$
E(k)=k-\left[k-\left(1-\frac{1}{k}\right)^{n}\right]
$$

where $E(k)$ is the expected number of patrilines in the colony, $k$ is the number of equally frequent patrilines and $n$ is the sample size.

We followed Oldroyd et al. [26] and numerically evaluated $k$ by substituting $E(k)$ with our observed number of matings $\left(n_{0}\right)$ and the worker sample sizes for $n$.

\subsubsection{Number of effective males $\left(\mathrm{m}_{\mathrm{e}}\right)$}

The average intracolonial relatedness $\bar{G}$ was estimated according to Estoup et al. [9]. Then, the number of effective males $\left(m_{\mathrm{c}}\right)$ was calculated following Chevalet and Cornuet [3]:

$$
m_{\mathrm{e}}=\frac{2}{4 \bar{G}-1}
$$

where $m_{\mathrm{e}}$ is the number of effective males and $\bar{G}$ is the average intracolonial relatedness.

\subsubsection{Genetic distance}

We used the standard genetic distance of [23]:

with

$$
D=-\ln \frac{J_{12}}{\sqrt{J_{1} J_{2}}}
$$

$$
J_{1}=\sum p_{i}{ }^{2}, J_{2}=\sum q_{i}{ }^{2} \text {, and } J_{12}=\sum p_{i} q_{i}
$$

where $J_{1}$ is the probability that two randomly chosen genes in population 1 are identical, $J_{2}$ is the same for population 2 , and $J_{12}$ is the proba- bility that two genes, one drawn randomly from population 1 and the other from population 2, are identical. This set was calculated for each of the four loci. Then, the average for all loci was calculated in each of the three cases: $\left(J_{1}, J_{2}, J_{12}\right)$.

\subsubsection{Improved Bonferroni procedure for $\chi^{2}$-tests}

We calculated a $\chi^{2}$-test for each allele at each locus to evaluate if the alleles shown by the drones which had mated with the queens on Baltrum, Norderney and Langeoog have a common allele pool or not. Since the high number of alleles at the used microsatellite loci may cause significant differences only by chance, we used an improved Bonferroni procedure $[16,32]$ to adjust the significance levels. We also used this procedure to combine the dependent test results because the test statistic cannot be split up into independent test statistics $[16,32]$. For $n$ test statistics, $q_{1}, q_{2}, \ldots, q_{n}$ and for $Q_{i}$ as a continuously distributed statistic for testing the null hypothesis $\mathrm{H}_{0, i}$ versus the alternative hypothesis $\mathrm{H}_{1, i}(i=1, \ldots ., n)$ the overall hypothesis $\mathrm{H}_{\mathrm{s}}$ is rejected if for at least one $i$ :

$$
p_{(i)}<\alpha_{(i)}
$$

where $p(i)$ are the ordered $p$-values for $\chi^{2}$-tests, $\alpha(i)$ is the significance level for the subhypothesis $\mathrm{H}_{i}$.

For each $\mathrm{H}_{i} \alpha_{(\mathrm{i})}$ was calculated as follows:

$$
\alpha_{(i)}=\frac{\alpha}{n-i+1}
$$

with $\alpha=0.05$.

\subsection{Putative origin of Baltrum worker bees' fathers}

The genotypes of all drones which mated with the tested Baltrum queens were compared with the genotypes of the drones which mated with the queens from Langeoog and Norderney. Baltrum drones showing allele combinations that did not correspond with the drone genotypes of one island were excluded from that potential source. Baltrum drone fathers which might potentially originate from the neighbouring island mating apiaries Langeoog or Norderney were determined and the differences in allele frequencies towards the drones which mated with the Langeoog and Norderney queens were evaluated using the Bonferroni procedure. 


\subsection{Comparisons of queen mating frequencies}

We computed Mann-Whitney U-tests to estimate potential differences for the number of observed and estimated queen matings and for the effective number of males between the three islands. To determine the probability of identical drone genotypes we estimated for each apiary the product of the highest allele frequency for each locus.

\section{RESULTS}

A total number of 996 workers was genotyped and assigned to patrilines (table $I$ ). Seventy-one patrilines were observed on Baltrum (table II). The ranges and the mean numbers $(x \pm \mathrm{SE}$.) of the observed and estimated queen matings and of the effective number of males for all three islands are given in table III. We found a mean number of $6.45 \pm 1.27$ observed queen matings on Baltrum. For Langeoog we found a mean of $12.5 \pm 1.23$ observed paternities. The mean number of observed matings was 12.8 \pm 2.27 on Norderney. For two colonies (L1 and N5) the estimated numbers of matings were substantially higher than the observed number of patrilines, which can be attributed to low sample sizes. Therefore, these colonies were excluded from the comparisons of queen mating frequencies. For the other colonies the number of estimated matings was slightly higher than the observed number of patrilines, showing that sample sizes were sufficiently large. We found significant differences for the number of observed and estimated queen matings and for the number of effective males between Baltrum and the neighbouring islands (Mann Whitney U-test: Baltrum/Langeoog $P<0.01$; Baltrum/Norderney $P<0.05$ ). However, we failed to detect significant differences between Langeoog and Norderney (Mann Whitney U-test: $P>0.05$ ). The allele frequencies for all tested microsatellite loci are given in table $I V$. Our results of the $\chi^{2}$-tests are shown in table $V$. We found for all tested drone populations with the excep- tion of the locus B124 in the case of Baltrum and Norderney significant differences for the allele frequencies at all loci. For Norderney $\chi^{2}$-tests were not calculated at the locus $\mathrm{A} 76$ because drones could be definitely excluded owing to specific alleles. Thus, we could exclude $43.7 \%$ of the Baltrum drones from any of the drone colonies on the adjacent islands. They most likely came from mainland colonies which were at least $5.4 \mathrm{~km}$ away. We found that $50.7 \%$ of the drones could have originated from the neighbouring island mating apiary Langeoog since they had genotypes in common with the corresponding drones. However, these drones potentially originating from Langeoog, showed significant differences in the allele frequencies of the drones which mated with the queens on Langeoog (table $V$ ). Four drones $(5.6 \%)$ which had mated with the Baltrum queens showed alleles common to both neighbouring mating apiaries and could not be excluded from any source.

The standard genetic distances between the tested populations are shown in table VI. High distances were observed between the drones mated with the queens from Norderney and the Baltrum patrilines and between the drones from Norderney and Langeoog whose drone mothers originated from unrelated breeding lines. This also shows that matings of the Baltrum queens with Norderney drones were most unlikely. An intermediate distance was observed between the drones from Baltrum and Langeoog. As expected, low distances were found between the tested sister queens.

\section{DISCUSSION}

Our results clearly show that successful mating flights took place on the drone-free island of Baltrum although the next available source of sexually mature drones was at least $5.4 \mathrm{~km}$ away.

The Baltrum queens showed a significantly smaller number of matings compared 
P. Neumann et al.

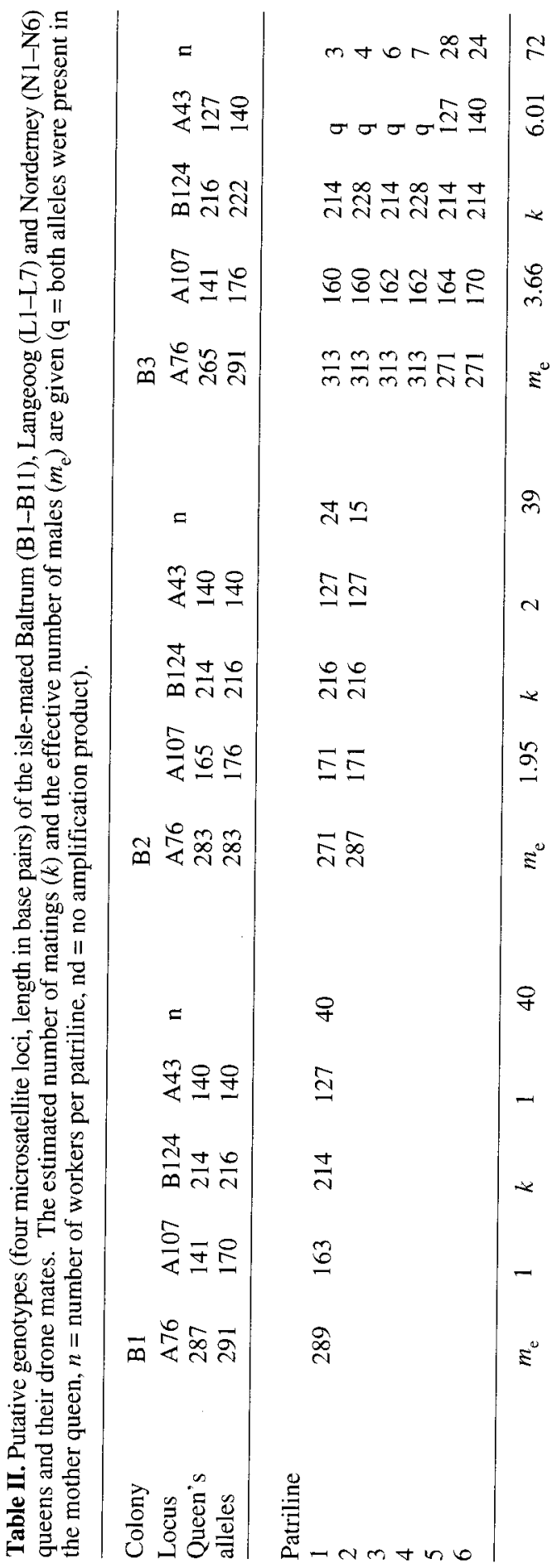




\begin{tabular}{|c|c|c|c|c|}
\hline$=$ & An nNm-ー & ले & $\Rightarrow$ & $m m n-N m+\infty n-$ \\
\hline 觉昌웜 & 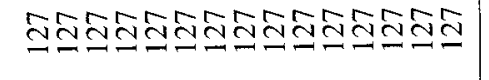 & 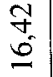 & 导果昌 & 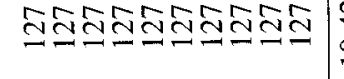 \\
\hline 志율 & 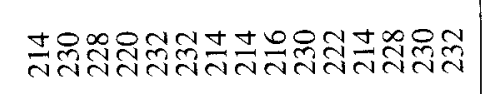 & $*$ & 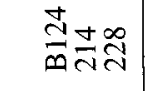 & 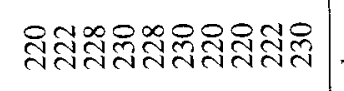 \\
\hline 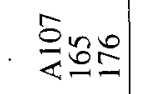 & 옹ㅇㅇㅇㅇㅇㅇㅗㅡニㅡㅡㅡㅡㅡㅡㅡㅡ & $\begin{array}{l}\mathcal{U} \\
\infty \\
\dot{I}\end{array}$ & 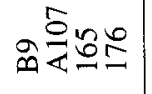 & 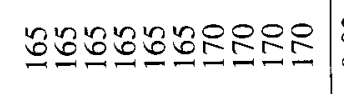 \\
\hline 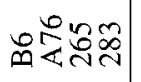 & 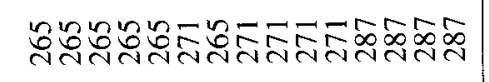 & $\cong$ & 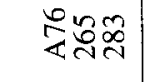 & 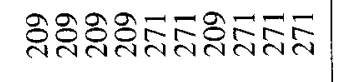 \\
\hline$=$ & 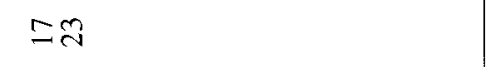 & \& & $a$ & $n-n d+6-t-m$ \\
\hline 路웜 & $\bar{\beth}_{\sigma}$ & $\sim$ & 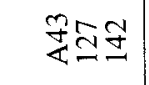 & 옹 웡웡워웡워워 \\
\hline 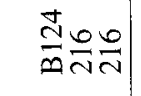 & $\stackrel{0}{2}$ & $*$ & $\stackrel{\Delta}{\stackrel{\Delta}{\Delta}} \frac{0}{\sim}$ & 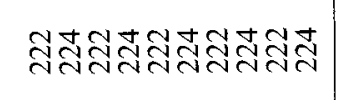 \\
\hline 운? & $2 E$ & $\underset{i}{8}$ & 은음 & 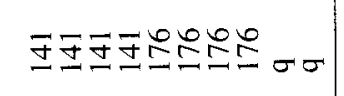 \\
\hline 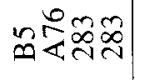 & वें & $\Xi$ & m்̃m & 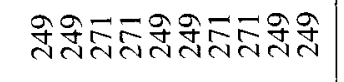 \\
\hline$=$ & ततntant? & F & $=$ & on? Ionint \\
\hline 离昌导 & 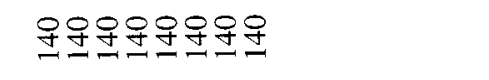 & $\underset{\infty}{ \pm}$ & 踣里寽 & 옴엄워웡워 \\
\hline 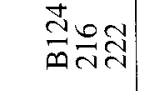 & 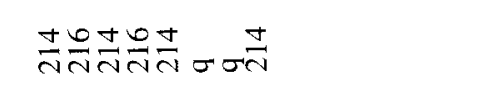 & $\approx$ & 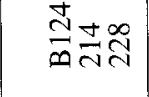 & 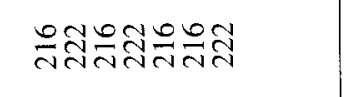 \\
\hline 원요 & 므요요으믐 & $\stackrel{a}{n}$ & $\frac{5}{2} 6$ & シミミミミミ \\
\hline षำ요 & 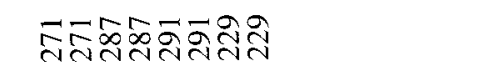 & $\Xi$ & ต뉴요 & 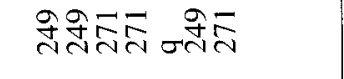 \\
\hline 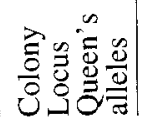 & $\stackrel{\mathscr{\Xi}}{:}$ & & 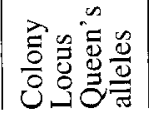 & 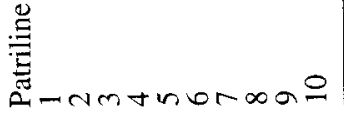 \\
\hline
\end{tabular}




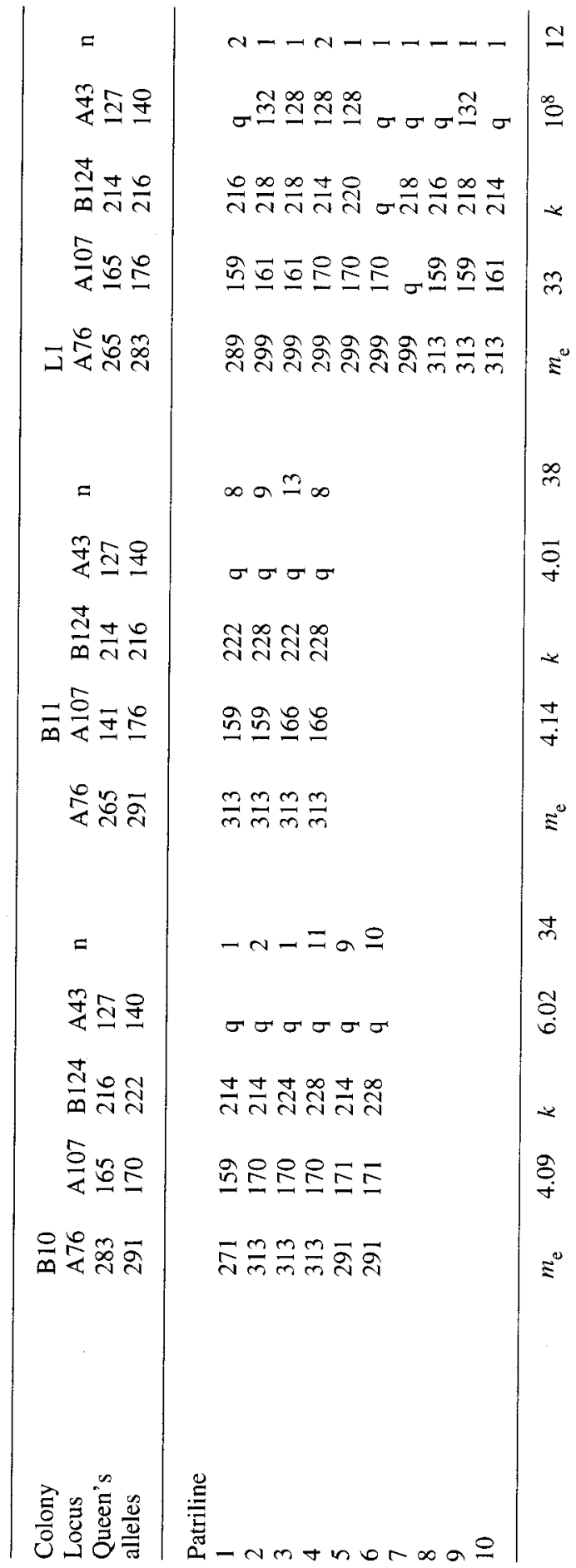




\begin{tabular}{|c|c|}
\hline$\simeq$ & 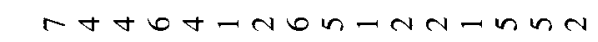 \\
\hline 学昌昌 & 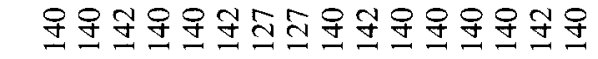 \\
\hline 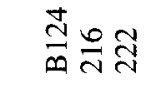 & 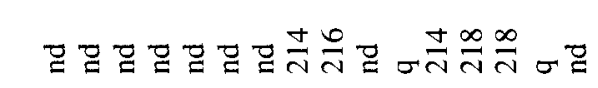 \\
\hline$\underset{8}{5} \stackrel{0}{2}$ & 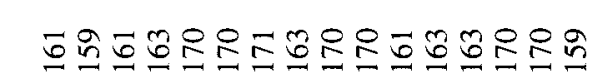 \\
\hline 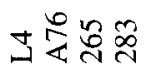 & 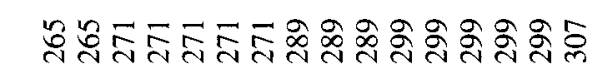 \\
\hline$=$ & $0 m+m a-n a-n-n-n-$ \\
\hline 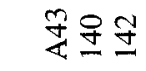 & 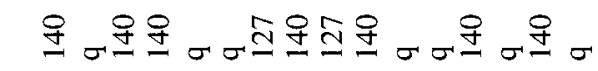 \\
\hline$\stackrel{d}{\Delta} \frac{\pi}{\sim}$ & 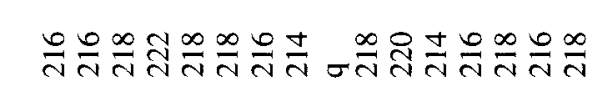 \\
\hline$\stackrel{5}{\text { ¿ }}$ & 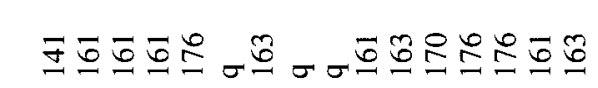 \\
\hline 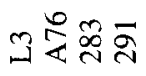 & 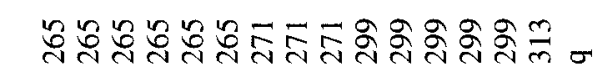 \\
\hline$=$ & ONNmN-D-Ninn- \\
\hline 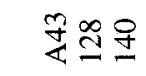 & 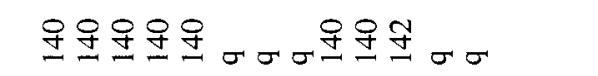 \\
\hline 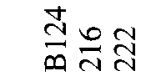 & 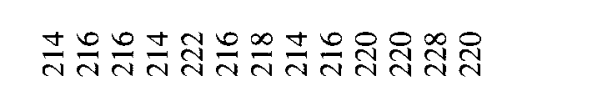 \\
\hline$\frac{5}{4}$ 은 & $\because \mathscr{0}$ \\
\hline 곤 & 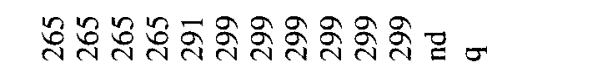 \\
\hline 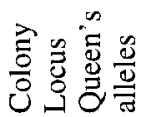 & 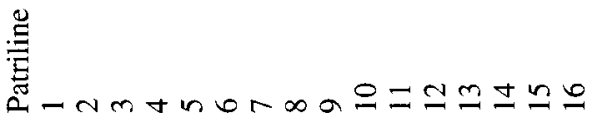 \\
\hline
\end{tabular}




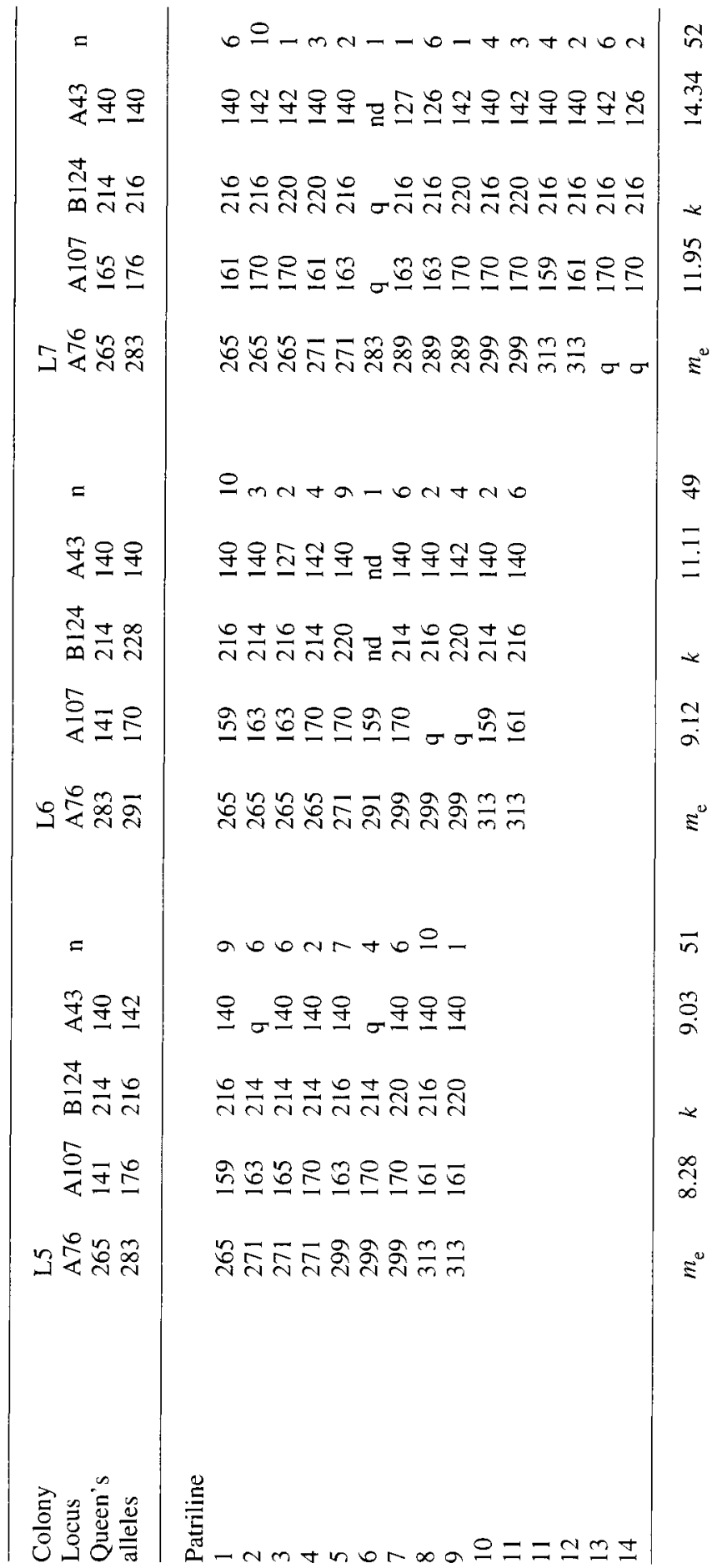




\begin{tabular}{|c|c|}
\hline$=$ & $m \subseteq m n-m m-m n t+n$ \\
\hline 学早等 & 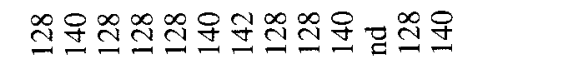 \\
\hline 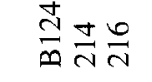 & 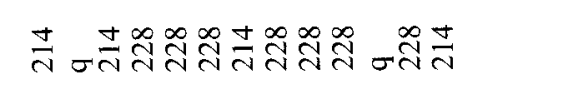 \\
\hline 完戸尺 & 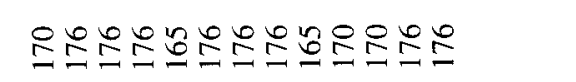 \\
\hline 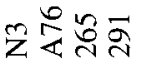 & 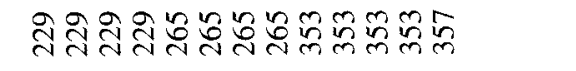 \\
\hline$=$ & $n-\nabla N N \nabla--ー-m \rightarrow N \infty \forall-$ \\
\hline 导昌界 & 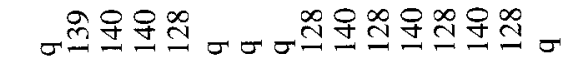 \\
\hline$\stackrel{ \pm}{ \pm} \frac{0}{N} \stackrel{N}{N}$ & 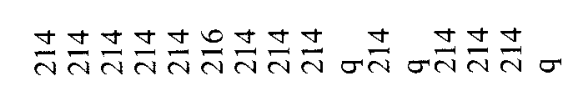 \\
\hline 它戸욘 & 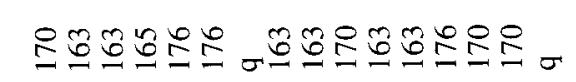 \\
\hline 눈? & 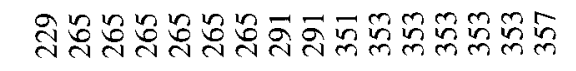 \\
\hline 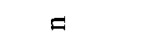 & $\Xi n N \forall b+$ \\
\hline 离导昌 & きさ先さ封す \\
\hline 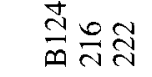 & মேন ন \\
\hline ํㅜㄴ은 & 오ㅇㅛㅛㅇㅡ \\
\hline 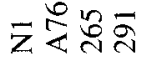 & 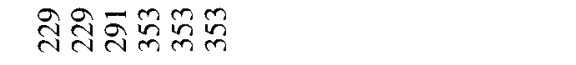 \\
\hline 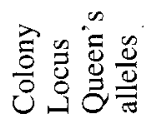 & : \\
\hline
\end{tabular}




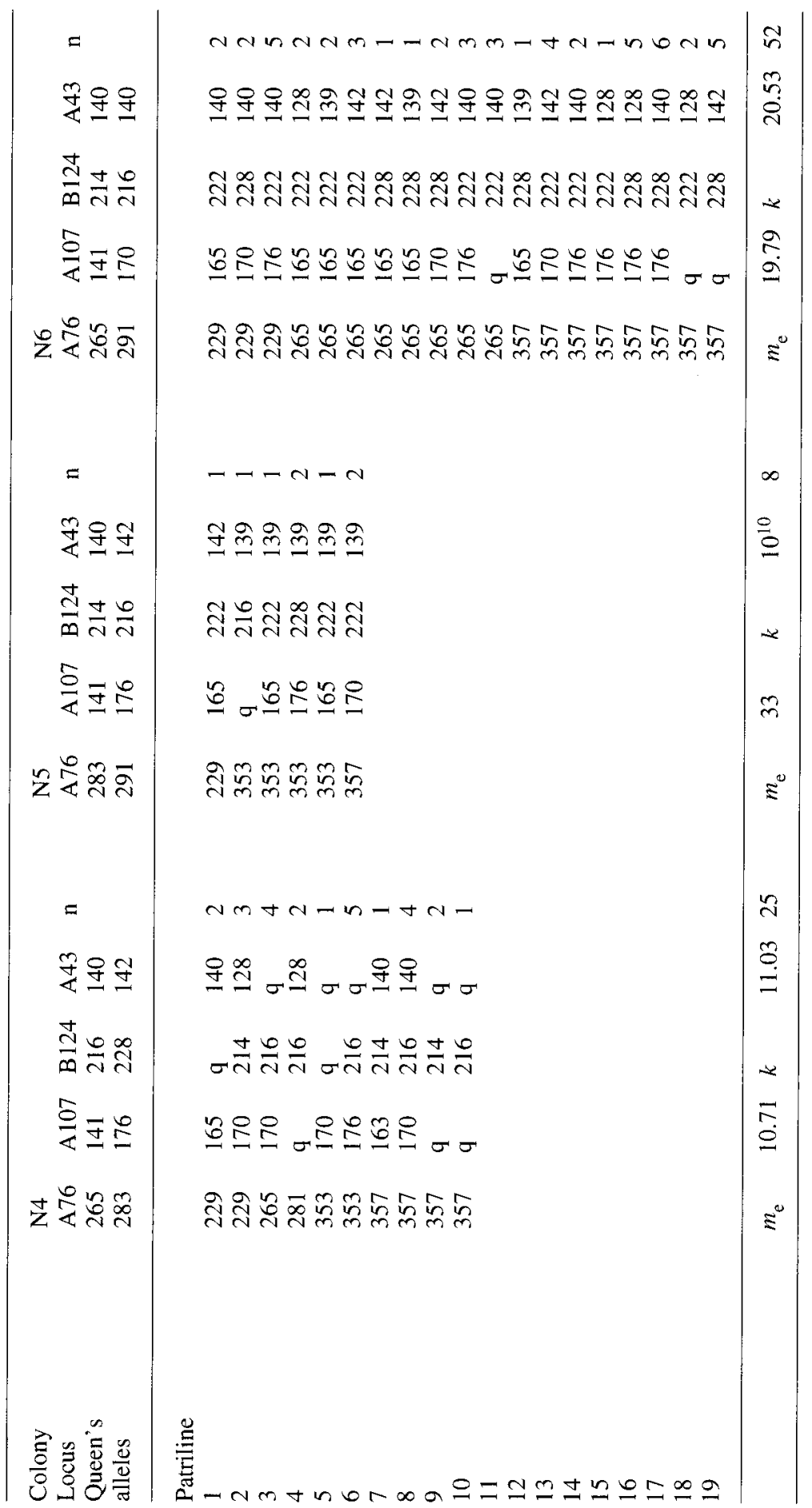


Table III. Range and mean numbers $\left(x \pm\right.$ SE) of the observed $\left(n_{0}\right)$ and estimated $(k)$ number of queen matings and the effective number of males $\left(m_{\mathrm{e}}\right)$.

\begin{tabular}{|c|c|c|c|c|c|c|}
\hline \multirow[t]{2}{*}{ Island } & \multicolumn{2}{|c|}{$\mathrm{n}_{\mathrm{o}}$} & \multicolumn{2}{|c|}{$k$} & \multicolumn{2}{|c|}{$m_{\mathrm{e}}$} \\
\hline & Range & Mean & Range & Mean & Range & Mean \\
\hline Baltrum & $1-15$ & $6.45 \pm 1.27$ & $1.00-16.42$ & $6.66 \pm 1.37$ & $1.00-14.82$ & $5.68 \pm 1.23$ \\
\hline Langeoog & $9-16$ & $12.5 \pm 1.23$ & $9.03-16.91$ & $13.70 \pm 1.26$ & $8.28-15.49$ & $11.79 \pm 1.11$ \\
\hline Norderney & $6-19$ & $12.8 \pm 2.27$ & $6.02-20.53$ & $13.73 \pm 2.53$ & $4.61-19.79$ & $11.93 \pm 2.43$ \\
\hline
\end{tabular}

to the queens which were mated on the neighbouring island mating apiaries. Potential differences in honeybee queen mating frequency which may be attributed to different types of mating apiaries [24] or to genetic variability among honeybee races (Neumann, unpublished data) can be excluded. Thus, the number of queen matings on Baltrum certainly depended upon the drone-free conditions, showing that mating conditions were much more difficult than under normal beekeeping practice.

The majority of the tested Baltrum queens $(81.8 \%)$ mated with males which most likely did not originate from the neighbouring island mating apiaries Langeoog and Norderney. These drones probably derived from colonies on the mainland more than $3 \mathrm{~km}$ away.

This is the second largest distance ever reported for successful honeybee mating flights across open water after those of Klatt [17, 18]. However, Evenius [12] doubted the drone-free conditions on the peninsula Frisches Haff during that time. In our experiment these drones could also potentially originate from undetected swarms on Baltrum. However, no drones could be attracted using a lure during normal drone flight activity [7]. Although we cannot definitely rule out that drones remained undetected in the lure experiments we consider it unlikely that the Baltrum queens have mated with drones from that island. It seems more likely that the queens fly to the mainland for mating. One could argue that the queens might have crossed the distance to the next available drone source while the mud flats around Baltrum fall dry at low tide. In light of the observations of Van Praagh et al. [33] this does not seem to play a role because queens returned from their nuptial flight with a mating sign even when the tide was high at Baltrum.

The allele combinations of the drones which mated with the Baltrum queens enabled us to exclude $43.7 \%$ of them from any of the used queens. Nine of eleven mated Baltrum queens certainly interacted with other drone sources probably from the mainland. An interaction with Norderney is unlikely because we could exclude the majority of the Baltrum patrilines from that origin $(94.4 \%)$. Furthermore, the potential 'Norderney' drones which mated with the Baltrum queens showed alleles (either $127 \mathrm{bp}$ for locus A43 or 291 bp for locus A76) which were very rare in the patrilines on Norderney. In the case of the potential Norderney drones, interactions with at least two different drone sources (Norderney and mainland or Norderney, Langeoog and mainland) must have occurred. Given that queens were searching for drones this seems to be most unlikely. It cannot be ruled out that $50.7 \%$ of the drones might originate from Langeoog which is $1.7 \mathrm{~km}$ over open water away. Two queens showed only potential Langeoog progeny in their worker offspring. However, we found significantly different allele frequencies between these potential 'Langeoog' drones and the drones 


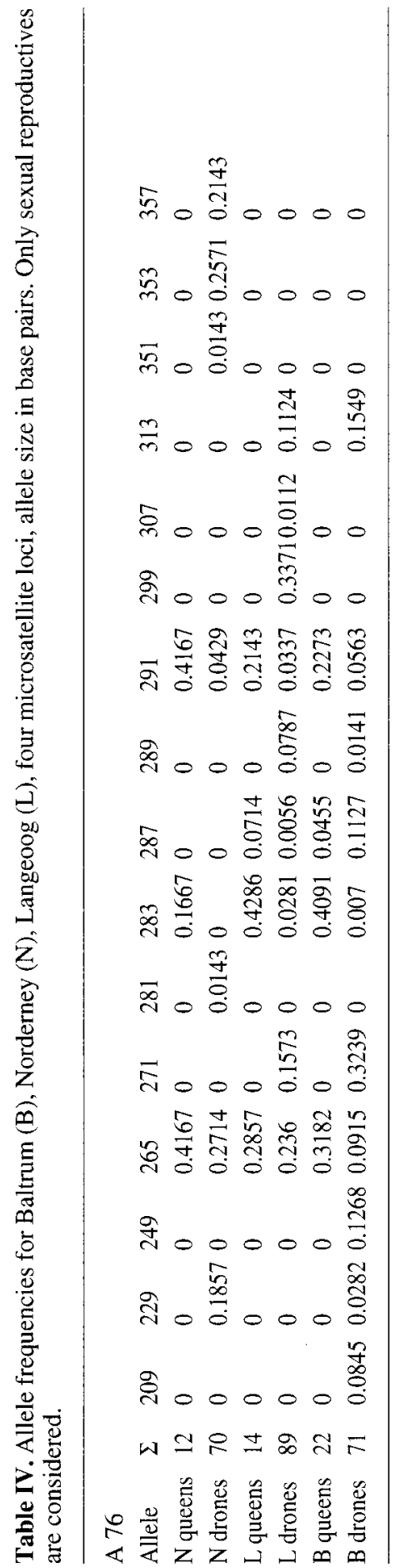

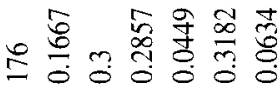
E00000咅

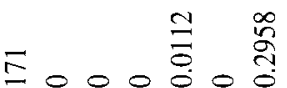

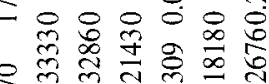

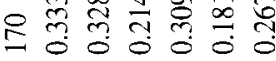

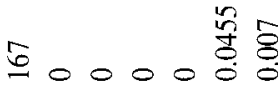
茴 $00000 \stackrel{\text { है }}{=}$

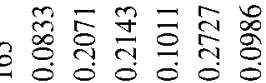
t. 00000 志 B. S. 00000 苛

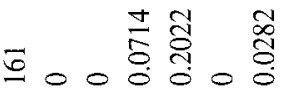
Q $000000 \stackrel{0}{0}$

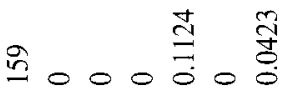

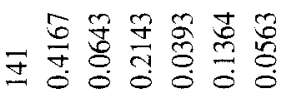

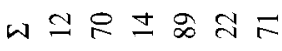

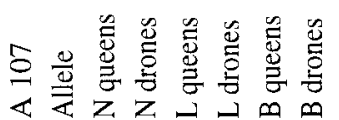

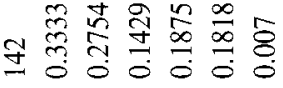
更

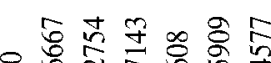

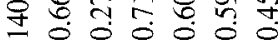

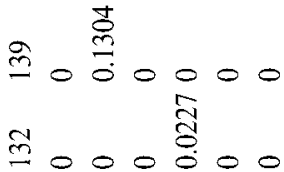

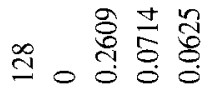

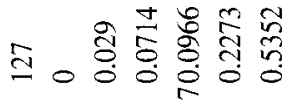
¿ 000 तิे g

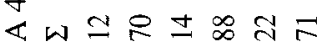
సี०0000 苦 总 0000 管势

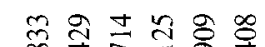
สํㅇㅇㅇ त् 范0000

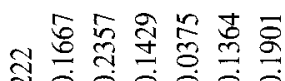
ส००००००0

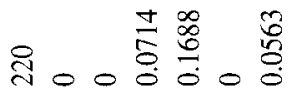
$\infty$ 는

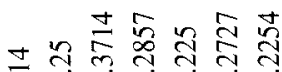

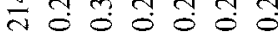
W $\simeq R \pm \otimes A 下$

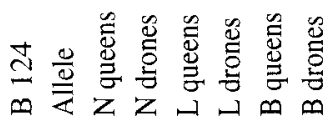




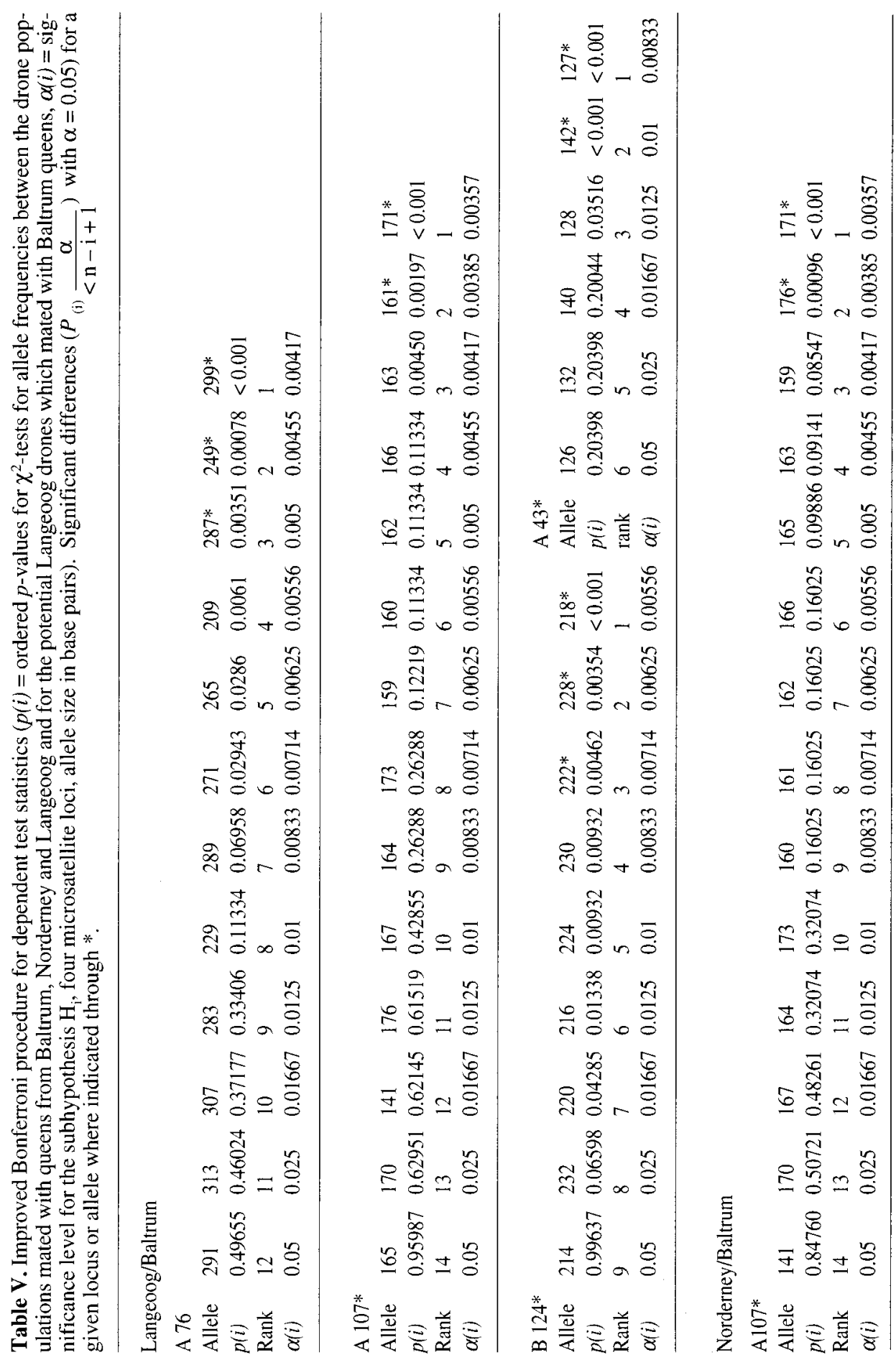




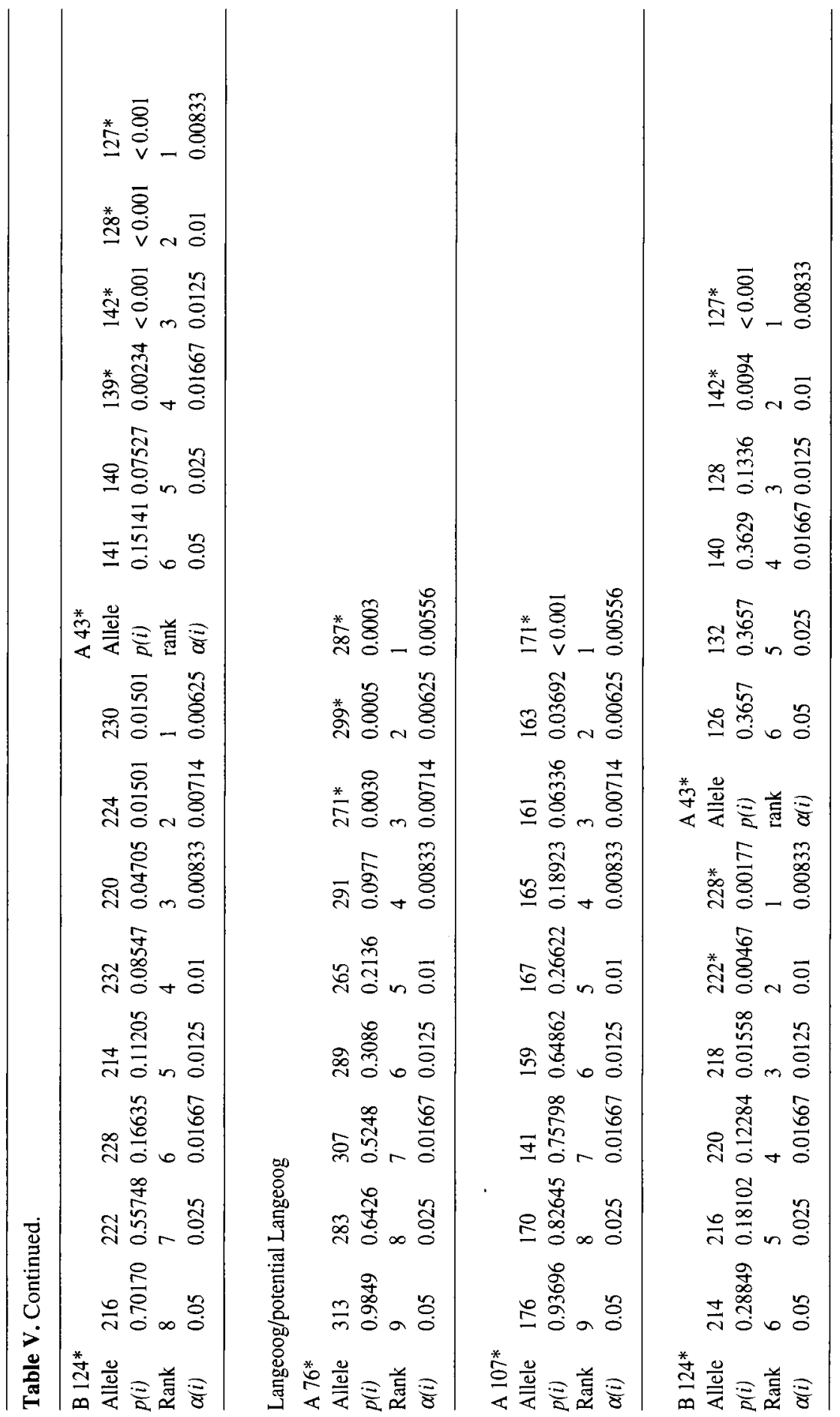


Table VI. Standard genetic distances (Nei, 1987) between the tested populations.

\begin{tabular}{lccccc}
\hline & $\begin{array}{c}\text { Langeoog } \\
\text { queens }\end{array}$ & $\begin{array}{c}\text { Norderney } \\
\text { queens }\end{array}$ & $\begin{array}{c}\text { Langeoog } \\
\text { drones }\end{array}$ & $\begin{array}{c}\text { Norderney } \\
\text { drones }\end{array}$ \\
\hline Baltrum queens & 0.029 & 0.129 & Baltrum drones & $\begin{array}{c}0.436 \\
0\end{array}$ & 0.673 \\
Langeoog queens & 0 & 0.098 & Langeoog drones & 0.502 \\
\hline
\end{tabular}

which mated with the Langeoog queens. We therefore reject the hypothesis that the drones originated from the same gene pool. Following our argumentation given for Norderney we consider it improbable that the queens had visited two possible drone sources during their mating flights. The standard genetic distances also indicate that matings with drones from the neighbouring island Norderney were unlikely.

This seems surprising in light of the small distance over open water between Norderney and Baltrum. Similarly, matings of the Baltrum queens with drones from the mainland were clearly indicated in spite of the largest distance over open water. These results show that a combination of distances over open water and over dry land is important to explain the observed mating behaviour of queens. Queen orientation flights during low tide [33], local wind directions, the southwest position of the sun during queen mating flight time in the afternoon and potentially more attractive visual cues provided by the mainland may also be important.

Our results show that queens most likely have the potential to successfully mate with mainland drones. Clearly, we cannot give a final judgement of the reliability of Baltrum as an established mating apiary. A reliability testing is only possible under normal beekeeping conditions with a sufficient number of drone colonies $[6,28]$. We consider it unlikely that queens would mismate if an adequate number of drones is available on Baltrum. Nevertheless, absolutely controlled matings such as with instrumental insemination cannot be guaranteed on the potential mating area Baltrum with the current state of evidence. We recommend a critical testing of island mating stations less than $8 \mathrm{~km}$ apart from the mainland [17, $18]$.

\section{ACKNOWLEDGEMENTS}

We are grateful to V. Schwarz for technical assistance. We wish to thank F.K. Böttcher for help during literature search. G. Koeniger, A. Stokes and two anonymous referees provided valuable comments on the manuscript. Financial support was granted by the DFG.

\section{Résumé - Fiabilité d'un rucher de fécon-} dation éventuel testée à l'aide de microsatellites d'ADN. Vingt-quatre reines sœurs ont été placées durant $21 \mathrm{j}$ sur l'île de Baltrum, qui est dépourvue de mâles, afin de tester la fiabilité d'une éventuelle station de fécondation. Sur chacune des îles voisines, Langeoog et Norderney, il y avait 12 autres reines sœurs avec des colonies de mâles (figure 1). Le tableau I donne les distances des colonies de Baltrum aux plus proches ruchers producteurs de mâles. On a prélevé des cadres de couvain d'ouvrières dans chacune des colonies possédant une reine fécondée ( $n=11$ à Baltrum ; $n=7$ à Langeoog et $n=6$ à Norderney). On a établi le génotype de 996 ouvrières fraîchement écloses en utilisant quatre locus différents de microsatellites d'ADN pour estimer la fréquence observée et la fréquence estimée d'accouplement des reines, ainsi que le nombre effectif de mâles (tableaux $I I$ et $I I I$ ), et pour obtenir l'origine supposée des mâles auxquels les reines de Baltrum s'étaient accou- 
plées. On a recherché entre les populations des différences éventuelles dans les fréquences alléliques à l'aide du test $\mathrm{Chi}^{2}$ (tableau IV) et de la méthode Bonferroni (tableau $V$ ) et calculé les distances génétiques selon Nei (tableau VI).

Les fréquences d'accouplement sur Baltrum ( $n=71$ accouplements $)$ sont significativement plus faibles que sur les stations des îles voisines (tableaux $I I$ et $I I$, test $\mathrm{U}$ de Mann-Whitney : Baltrum/Langeoog $p>0,01$; Baltrum/Norderney $p<0,05$ ). On n'a pas trouvé de différence dans la fréquence d'accouplement entre les îles Langeoog et Norderney, ce qui laisse penser que les conditions d'accouplement sur l'île de Baltrum sont plus difficiles. Les mâles qui s'étaient accouplés avec les reines de $\mathrm{Bal}$ trum présentaient des combinaisons d'allèles qui ne correspondaient pas aux génotypes des mâles des îles voisines. $43,7 \%$ des mâles identifiés ne provenaient pas des colonies de mâles des îles voisines. Ils venaient selon toute vraisemblance du continent; ils avaient donc survolé la mer sur une distance d'au moins $5,4 \mathrm{~km}$ (tableau $I$ ). On ne peut pas exclure que $50,7 \%$ des mâles provenaient de Langeoog. Ces mâles présentaient néanmoins des fréquences alléliques significativement différentes de celles des mâles qui s'étaient accouplés avec les reines de Langeoog (tableau V). Quatre mâles avaient des allèles présents dans les deux stations de fécondation et aucune origine ne pouvait être exclue pour eux. Les populations de mâles de Langeoog et de Norderney et les lignées paternelles de Baltrum ont présenté des fréquences alléliques significativement différentes (tableau $V$ ). Cela signifie que les accouplements entre les mâles de Langeoog ou de Norderney et les reines de $\mathrm{Bal}$ trum sont improbables. On a trouvé une distance génétique élevée entre les mâles de Norderney et de Baltrum (tableau VI), ce qui montre aussi que les accouplements avec des mâles de Norderney sont très improbables, bien que la distance à parcourir audessus de la mer soit plus faible. Ces résultats montrent qu'il est important pour le comportement d'accouplement des reines de Baltrum de combiner les distances à parcourir au-dessus de la mer et au-dessus de la terre ferme jusqu' aux colonies de mâles les plus proches (tableau I).

Le problème reste ouvert de savoir si des reines qui s'accouplent dans des conditions normales, i.e. avec un nombre satisfaisant de colonies de mâles, sur une station de fécondation établie à Baltrum, s'accouplent aussi avec des mâles non sélectionnés, puisque l'installation de reines vierges sans colonies de mâles ne convient pas en conditions de routine pour évaluer la fiabilité d'une station de fécondation. Nos résultats montrent pourtant de façon claire que des accouplements contrôlés ne peuvent pas être garantis sur l'île de Baltrum. Soit les mâles, soit les reines, soit les deux sexes sont capables de franchir de grandes distances au-dessus de la mer lors de leurs vols de fécondation. Nous recommandons donc de tester la fiabilité des stations de fécondation situées sur des îles à moins de $8 \mathrm{~km}$ du continent. (C) Inra/DIB/AGIB/Elsevier, Paris

\section{Apis mellifera / accouplement controlé / polyandrie / île /microsatellite}

\section{Zusammenfassung - Prüfung der Paa- rungssicherheit einer potentiellen Insel- belegstelle mit DNA-Microsatelliten. Vier- undzwanzig Geschwisterköniginnen wur- den für 21 Tage auf der drohnenfreien Insel Baltrum plaziert, um die Zuverlässigkeit einer potentiellen Belegstelle zu testen. Auf den benachbarten Inseln Langeoog und Nor- derney standen je 12 weitere Geschwisterkö- niginnen mit Drohnenvölkern (Abbildung I). Die Abstände von den Baltrum Völkern zu den nächsten Drohnen produzierenden Bie- nenständen sind Tabelle I zu entnehmen. Aus jedem Volk mit einer begatteten Köni- gin ( $n=11$ Baltrum; $n=7$ Langeoog und $n=6$ Norderney) wurden Arbeiterinnen- brutwaben entnommen. Isolierte, frisch geschlüpfte Arbeiterinnen $(n=996)$ wur- den unter Verwendung vier verschiedener DNA Microsatelliten Loci genotypisiert}


(Tabelle $I I$ ), um die beobachtete und geschätzte Paarungshäufigkeit der Königinnen sowie die effektive Anzahl an Männchen abzuschätzen (Tabellen $I I$ und $I I I$ ) und um die vermutliche Herkunft der Drohnen mit denen sich die Baltrum Königinnen gepaart haben zu ermitteln. Zwischen den getesteten Populationen wurden mögliche Unterschiede in den Allelfrequenzen (Tabelle IV) mit Hilfe von $\chi^{2}$-Tests und der Bonferroni Methode untersucht (Tabelle $V$ ) und die genetischen Distanzen nach Nei berechnet (Tabelle VI). Die Paarungshäufigkeiten auf Baltrum ( $n=71$ Paarungen) waren signifikant geringer als auf den benachbarten Inselbelegstellen (Tabellen II, III, Mann Whitney U-test: Baltrum/Langeoog $p<0,01$; Baltrum/Norderney $p<0,05$ ). Es konnten keine Unterschiede in der Paarungshäufigkeit zwischen Langeoog und Norderney gefunden werden (Mann Whitney U-test: $p>0,05$ ), was darauf hindeutet, da $\beta$ die Paarungsbedingungen auf Baltrum erschwert sind. Die Drohnen, mit denen sich die Baltrum Königinnen gepaart haben, konnten aufgrund ihrer Allele nicht von den Nachbarinseln stammen. $43,7 \%$ der identifizierten Drohnen stammen nicht von den Drohnenvölkern der benachbarten Inseln. Sie kamen am wahrscheinlichsten vom Festland, das am weitesten über offenes Wasser entfernt lag (Tabelle I). Es kann nicht ausgeschlossen werden, da $\beta 50,7 \%$ der Drohnen von Langeoog stammen. Diese Drohnen zeigten jedoch signifikant unterschiedliche Allelfrequenzen zu den Drohnen, mit denen sich die Langeoog Königinnen gepaart haben (Tabelle $V$ ). Vier Drohnen wiesen auf beiden Belegstellen vorkommende Allele auf und konnten von keiner Herkunft ausgeschlossen werden. Signifikant unterschiedliche Allelfrequenzen (Tabelle $V$ ) zeigten die Drohnen Populationen von Langeoog und Norderney und die Patrilinien von Baltrum. Dies deutet daraufhin, da $\beta$ Paarungen zwischen Drohnen von Langeoog oder Norderney und den Königinnen von Baltrum unwahrscheinlich sind. Eine hohe genetische Distanz wurde zwischen den Drohnen von Norderney und Baltrum gefunden (Tabelle VI), was ebenfalls zeigt, da $\beta$ Paarungen mit Drohnen von Norderney am unwahrscheinlichsten sind, obwohl die Entfernung über offenes Wasser am geringsten ist. Diese Ergebnisse deuten daraufhin, daß eine Kombination aus Entfernungen über Wasser und über Land zu den nächsten Drohnenvölkern für das Paarungsverhalten der Baltrum Königinnen von Bedeutung ist (Tabelle I). Ob sich Königinnen unter regulären Bedingungen auf einer etablierten Belegstelle Baltrum, d.h. mit einer ausreichenden Anzahl von Drohnenvölkern, auch mit unselektierten Drohnen paaren, bleibt offen, da das Aufstellen unbegatteter Königinnen ohne Drohnenvölker nicht für die Einschätzung der Zuverlässigkeit einer Belegstelle unter Routinebedingungen geeignet ist. Unsere Ergebnisse demonstrieren jedoch eindeutig, da $\beta$ auf Baltrum kontrollierte Paarungen nicht garantiert werden können. Entweder Drohnen oder Königinnen oder beide Geschlechter sind in der Lage, bei ihren Paarungsflügen größere Strecken offenen Wassers zu überqueren. Wir empfehlen daher eine Überprüfung der Sicherheit von Inselbelegstellen, die weniger als $8 \mathrm{~km}$ vom Festland entfernt liegen. (1) Inra/DIB/AGIB/Elsevier, Paris

\section{Apis mellifera / Insel / DNA-Microsatelliten / Paarungskontrolle / Polyandrie}

\section{REFERENCES}

[1] Beye M., Raeder U., Rapid DNA preparation from bees and \% GC fractionation, Bio Techniques, 14 (1993) 372-374.

[2] Böttcher F.K., Was taugt die Belegstelle?, Der Imkerfreund 2 (1947) 1 I5-1 16.

[3] Chevalet C., Cornuet J.M., Etude théorique sur la sélection du caractère «production du miel» chez l'abeille. I . Modèle génétique et statistique, Apidologie 13 ( 1982) 39-65.

[4] Cornuet J.M., Aries F., Number of sex alleles in a sample of honeybee colonies, Apidologie 11 (1980) 87-93.

[5] Drescher W., Untersuchungen zur Zuflugsicherheit der Inselbelegstelle Mellum, Z. Bienenforsch 8 (3) (1965) 49-53. 
[6] Drescher W., Betrachtungen zum Thema Belegstellen, Allg. Dtsch. Imkerztg. (8) (1974) 57-62.

[7] Dustmann J.H., van Praagh J.P., Faltus E., Maarzahl H., Die Insel Baltrum als Belegstelle?, Dtsch. Bienen. J. 4 (6) (1997) 266.

[8] Estoup A., Solignac M., Harry M., Cornuet J.M., Characterisation of (GT)n and (CT)n microsatellites in two insect species: Apis mellifera and Bombus terrestris, Nucleic Acids Res. 21 (1993) 1427-1431.

[9] Estoup A., Solignac M., Cornuet J.M., Precise assessment of the number of patrilines and genetic relatedness in honeybee colonies, Proc. $\mathrm{R}$. Soc. Lond. B 258 (1994) 1-7.

[10] Evenius J., Königinnenzuchtversuche auf der Greifswalder Oie, Leipz. Bienenztg. 44 (12) (1929) 244.

[11] Evenius J., Zur Frage der Belegstellen, Westf. Bienenztg. 45 (1930) 293-294.

[12] Evenius J., Die neuzeitliche Bienenzucht und die Verwendung von Inseln als Belegstellen, Bienenwirtsch. Zentrbl. (4) (1931) 92-95.

[13] Frumhoff P.C., The effect of the cordovan marker on apparent kin discrimination among nestmate honeybees, Anim. Behav. 42 (1991) 854-856.

[14] Gary N.E., Observations of mating behaviour in the honeybee, J. Apic. Res. 2 (1963) 3-13.

[15] Heran H., Lindauer M., Windkompensation und Seitenwindkorrektur bei Flug über Wasser, Z. Vgl. Physiol.47 (39) (1963) 39--55.

[16] Hochberg Y., A sharper Bonferroni procedure for multiple tests of significance, Biometrics 75 (1988) 800-802.

[17] Klatt G., Züchtungsmöglichkeiten an der Wasserkante, Arch. Bienenkd. X 8 (1929) 318-321.

[18] Klatt G., Unsere ostpreußischen Belegstellen, Die deutsche Bienenzucht in Theorie und Praxis 37 (3) (1929) 74-77.

[19] Klöpping B., Hompelvoet is getest, Buckfast Bull. 16 (1993) 15.
[20] Meinen G., Wie sicher ist die Inselbelegstelle Spiekeoog vor fremdrassigem Drohnenzuflug?, NW Dtsch. Imkerztg. 22 (1970) 128-130.

[21] Minderhoud M., Verslag der proeven over koniginnenentelt op Urk, Maandschrift voor Bijeenteelt 26 (3) (1923) 40.

[22] Moritz R.F.A., Homogenous mixing of honeybee semen by centrifugation, J. Apic. Res. 22 (1983) 249-255

[23] Nei M., Molecular Evolutionary Genetics, Columbia University Press, New York, 1987.

[24] Neumann P., Moritz R.F.A., van Praagh J., Queen mating-frequency in different types of honeybee mating apiaries, J. Apic. Res. 38 (1999) in press.

[25] Oertel E., Observations on the flight of drone honey bees, Ann. Entomol. Soc. Am. 49 (1956) 497-500.

[26] Oldroyd P.B., Clifton M.J., Wongsiri S., Rinderer T.E., Sylvester H.A., Crozier R.H., Polyandry in the genus Apis, particularly Apis andreniformis, Behav. Ecol. Sociobiol. 40 (1997) 17-26.

[27] Oortman Gerling E., Betrouwbaarheids-proef op Marken 1992, Buckfast Bull. 15 (1993) 31-32.

[28] Ruttner F., Drohnenflugweite und Drohnendichte, Dtsch. Bienenwirtsch. 10 (1) (1959) 42-47.

[29] Ruttner F., Ruttner H., Wie weit fliegen Drohnen und Königinnen?, Bienenvater 86 (1) (1965) 15-21.

[30] Sladen F.W.L., Why young queens may fail, Glean. Bee Cult. 48 (2) (1920) 50-52.

[31] Sladen F.W.L., Queen mating experiments, Ebenda 48 (12) (1920) 717-718.

[32] Simes R.J., An improved Bonferroni procedure for multiple tests of significance, Biometrics 73 (1986) 751-754.

[33] Van Praagh J., Neumann P., Moritz R.F.A., Koeniger G. and Dustmann J.H., Mating behaviour of honeybee queens (Apis mellifera $\mathrm{L}$.) on an island free of drones, Pszcz. Zesz. Nauk. XL 2 (1997) 25-32

[34] Zander E., Böttcher F.K., Haltung und Zucht bei der Biene, Eugen Ulmer Verlag, Stuttgart, 1989. 